\title{
Age related decrease of NOR activity in bone marrow metaphase chromosomes from healthy individuals
}

Estela Pedrazzini, Nikolai Mamaev, Irma Slavutsky

\begin{abstract}
Aims-To present data obtained from human bone marrow preparations from healthy individuals showing that the proportion of metaphases with silver stained nucleolar organiser region (AgNOR) chromosomes is associated with the age of the donor.

Methods-Bone marrow preparations from eight Russian and 10 Argentinian healthy individuals donating bone marrow for heterologous transplantation were studied by silver staining. The Russian bone marrow preparations were used directly, while the bone marrow specimens from Argentinian donors were incubated for 24 hours at $37^{\circ} \mathrm{C}$ in $\mathrm{F}-10$ medium with $15 \%$ fetal bovine serum. The slides were silver stained by the one step method of Howell and Black with slight modifications. Thirty metaphases with clearly defined $D$ and $G$ group chromosomes were scored for the numbers of AgNORs. All metaphases that were adjacent to silver stained interphase nuclei were analysed to assess the percentage of AgNOR positive mitoses. The Kruskal Wallis test and Kendall's rank correlation coefficient (rK) were used to assess the relation between age and the percentage of AgNOR positive cells.
\end{abstract}

Results-The mean numbers (SE) of AgNORs per metaphase were $5.06(0.17)$ and $5.56(0.23)$ for the Russian and Argentinian groups, respectively, with no significant differences between the two groups. The common percentage of AgNOR positive cells decreased significantly as a function of age, with an $\mathbf{r K}=-0.57(\mathrm{p}<0.0012)$.

Conclusions-The percentages of AgNOR negative metaphases in bone marrow from healthy individuals is strongly associated with age and this may be related to age related telomere loss.

(f Clin Pathol:Mol Pathol 1998;51:39-42)

Keywords: nucleolar organiser regions; silver staining; healthy human beings; aging

A cytochemical silver nitrate technique can be used effectively to monitor the activity of ribosomal RNA cistrons because a subset of nucleolar argentophilic proteins are associated with transcriptionally active rDNA. ${ }^{1}$ According to recent findings, the proteins responsible for nucleolar organiser regions silver staining (AgNORs) on metaphase chromosomes in- clude RNA polymerase I, topoisomerase II $\alpha$, transcription factor UBF, and probably nucleolin. ${ }^{2}$ Studies on the AgNOR staining pattern in bone marrow cells from donors and patients with haematological malignancies have revealed significant decreases of modal AgNOR classes as well as a high percentage of AgNOR negative mitoses (mean, $48 \%$; range, 34-70\%) compared with PHA stimulated lymphocytes from the same subjects. ${ }^{3-13}$ On the basis of these data, a hypothesis was put forward which related the AgNOR negative mitoses in bone marrows from healthy individuals and patients with leukaemias to polychromatic normoblasts and myelocytes, whose activity with regard to the synthesis of rRNA was clearly decreased..$^{4-612} 14$ This hypothesis has been verified by analysing the pattern of AgNOR staining in interphase nuclei of bone marrow erythroid and granulocytic elements of various maturities obtained from healthy donors and patients with leukaemias. ${ }^{25-7} 12$ 14-18

Recently, Pedrazzini and Slavutsky noted that the AgNOR pattern of normal bone marrow cells is age related, but that this phenomenon is not seen in patients with mycosis fungoides ${ }^{13}$ and acute lymphoblastic leukaemia (unpublished data). Additional analysis of our previously published data ${ }^{5}$ also supported this conclusion.

\section{Materials and methods}

Bone marrow samples were obtained from eight Russian ${ }^{5}$ and 10 Argentinian healthy individuals donating bone marrow for heterologous transplantation (table 1 ).

The Russian bone marrow preparations were made from aspirates of the sternum, fixed in 3:1 methanol:acetic acid for 10 minutes, and air dried smeared. ${ }^{5}$ Bone marrow samples from Argentinian donors were incubated for 24 hours at $37^{\circ} \mathrm{C}$ in $\mathrm{F}-10$ medium with $15 \%$ fetal bovine serum. Colcemid (final concentration $0.1 \mu \mathrm{g} / \mathrm{ml}$ ) was added 40 minutes before harvesting. Cells were incubated in $0.075 \mathrm{M}$ $\mathrm{KCl}$ for 20 minutes at $37^{\circ} \mathrm{C}$, pelleted, and fixed in methanol:glacial acetic acid (3:1). After the cells had been washed three times in the fixative, air dried slides were prepared. In both cases, the slides were stained with the one step method of Howell and Black ${ }^{19}$ that uses gelatine as the silver colloidal protector and pretreatment in $2 \mathrm{M}$ formic acid for 10 minutes to improve the evaluation of AgNORs in bone marrow cells. A total of 30 metaphases with clearly defined D and G group chromosomes were scored for the mean number of AgNORs. All metaphases that were adjacent to 
Table 1 Frequency of AgNORs in bone marrow cells

\begin{tabular}{|c|c|c|c|c|}
\hline Sample & Age/sex & $\begin{array}{l}\text { Mean number } \\
\text { of AgNORs }\end{array}$ & $\begin{array}{l}\text { Cells } \\
\text { scored (n) }\end{array}$ & $\begin{array}{l}\text { AgNOR+ } \\
\text { cells (\%) }\end{array}$ \\
\hline$\star 1$ & $8 / \mathrm{F}$ & 7.37 & 230 & 58.7 \\
\hline$\dagger 2$ & $14 / \mathrm{M}$ & 4.30 & 136 & 62.0 \\
\hline+3 & $16 / \mathrm{M}$ & 4.80 & 34 & 89.5 \\
\hline+4 & $17 / \mathrm{M}$ & 5.40 & 43 & 60.0 \\
\hline+5 & $18 / \mathrm{M}$ & 5.40 & 82 & 78.8 \\
\hline+6 & $18 / \mathrm{M}$ & 5.40 & 89 & 53.7 \\
\hline$\star 7$ & $22 / \mathrm{M}$ & 5.73 & 200 & 75.0 \\
\hline+8 & $22 / \mathrm{F}$ & 4.40 & 70 & 68.6 \\
\hline †9 & $22 / \mathrm{M}$ & 5.40 & 111 & 56.0 \\
\hline$\star 10$ & $24 / M$ & 5.80 & 178 & 64.6 \\
\hline$\dagger 11$ & $25 / M$ & 5.40 & 131 & 56.0 \\
\hline$\star_{12}$ & $28 / \mathrm{F}$ & 5.30 & 640 & 49.6 \\
\hline$\star 13$ & $29 / M$ & 4.97 & 286 & 49.1 \\
\hline$\star \star 14$ & $35 / \mathrm{M}$ & 5.20 & 548 & 35.6 \\
\hline$\star 15$ & $38 / \mathrm{F}$ & 4.77 & 254 & 22.0 \\
\hline$\star 16$ & $40 / \mathrm{F}$ & 5.80 & 355 & 20.0 \\
\hline$\star^{\star} 17$ & $40 / \mathrm{M}$ & 5.43 & 307 & 56.0 \\
\hline${ }^{\star} 18$ & $53 / \mathrm{M}$ & 5.20 & 368 & 37.1 \\
\hline Mean (SE) & $19.0(1.3)$ & $5.34(0.15)$ & & $55.1(3.7)$ \\
\hline
\end{tabular}

^Argentinean donor; †Russian donor.

silver stained interphase nuclei were analysed to assess the percentages of AgNOR positive mitoses.

Because the data for the bone marrow samples were not distributed normally, we used the Kruskal-Wallis test to compare groups and the Kendall's rank correlation coefficient (rK) for the relation between age and the percentage of AgNOR positive cells.

\section{Results}

Results from the silver staining of normal bone marrow cells are summarised in table 1 . Among the 10 potentially stainable chromosomes the mean (SE) numbers of AgNORs per metaphase were $5.06(0.17)$ and $5.56(0.23)$ for the Russian and Argentian groups, respectively. There were no significant differences between the two groups, with a mean (SE) of 5.34 (0.15) AgNOR chromosomes per bone marrow cell when the two groups were analysed together. As regards the proportion of mitoses demonstrating silver staining on at least one chromosome, when the two groups were analysed together the mean (SE) was $55.1 \%(3.7 \%)$; when the two groups were analysed separately, the results were $65.6 \%(4.5 \%)$ and $46.8 \%$ (5.7\%) for the Russian and Argentinian groups, respectively, with a significant difference between them $(p<0.04)$. Upon analysis, it was apparent that each group had a different mean age $(p<0.01)$; accordingly, we

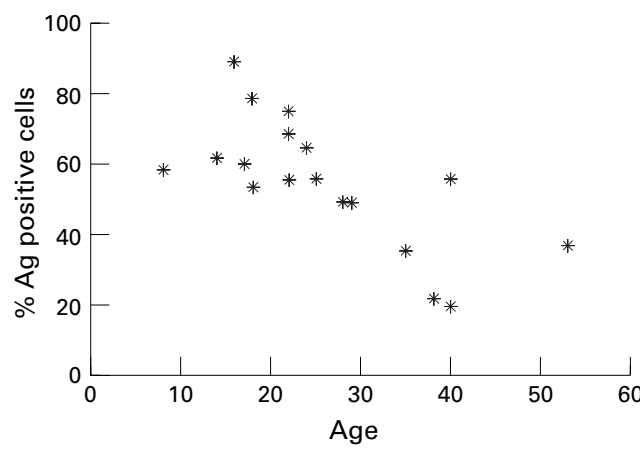

Figure 1 Scatter diagram showing the correlation between the percentage of $\mathrm{AgNOR}$ positive mitoses and aging. There is a significant negative correlation, $r K=-0.57$, $p<0.0012$. examined the relation between the percentage of AgNOR positive mitoses and the age of the bone marrow donors. We found that the percentage of AgNOR positive cells decreased significantly in function with age, with an $\mathrm{rK}=-0.57(\mathrm{p}<0.0012)($ fig 1$)$.

\section{Discussion}

The above results show that the percentage of AgNOR negative metaphases in bone marrow from healthy individuals is associated strongly with age. In relation to these findings, it must be remembered that AgNOR negative mitoses in normal bone marrow are mainly present in erythroid and granulocytic elements. The latter finding has been shown by us in patients with multiple myeloma, where all mitoses of diseased cells (with chromosome markers) were AgNOR positive, whereas the majority of AgNOR negative mitoses were in cells with a normal karyotype.

As discussed, the technical approaches used by the two laboratories participating in this study were not identical. Nevertheless, similar data were obtained, although the more active erythroid precursors appear to be the main mitotic cells in the bone marrow preparations from the Russian donors. On the other hand, the great majority of mitoses from the short term bone marrow cultures of the Argentinian controls are of granulocytic origin because cultured erythroid cells cannot grow effectively without the addition of erythropoietin. Accordingly, it is not surprising, that the mean number (SE) of AgNOR positive metaphases in the Russian samples was significantly higher than that found in the Argentinian samples $(65.6 \%$ $(4.5 \%)$ and $46.8 \%(7 \%)$, respectively; $\mathrm{p}<0.04)$. These findings are in agreement with earlier published data related to age dependent decreases in the numbers of $\mathrm{Ag}$ NORs in PHA stimulated human lymphocytes. ${ }^{20-23}$ The relevant investigators related these findings to either a progressive decrease of lymphocyte proliferative activity ${ }^{21}{ }^{24}$ or a hypothetical progressive inactivation of rRNA genes with aging. ${ }^{202}$ Also, there is little evidence of an expected age related decrease in proliferative activity of erythroid and granulocytic precursors. ${ }^{25} 26$ Meanwhile, there is increasing evidence that anaemia and leucocyte abnormalities in otherwise healthy elderly patients are not a normal physiological consequence of aging, but rather result from multiple insults and increased haemopoietic demands. ${ }^{26}$

In the light of these controversial ideas it seems that there may be a relation between the number of AgNORs in interphase nuclei and their indices of proliferative activity. This evidence is indirect, despite the fact that nucleolar argentophilic proteins such as RNA polymerase I, topoisomerase II $\alpha$, transcription factor UBF, and nucleolin ${ }^{2}$ can be good markers of cell proliferation. It is likely that cells need rDNA expression, ribosome formation, and protein synthesis not only for proliferation but also for differentiation, maturation, repair, and so on. ${ }^{12}$ Hence, the age related AgNOR positive proportion of cells may decrease in 
haemopoietic precursors to compensate/repair haemopoiesis in relation to insults to the haemopoietic system without a decrease in the proliferative activity of erythroid and granulocytic lineages. This would be in agreement with many clinical findings. ${ }^{27-32}$

A possible factor that could be very closely related to bone marrow failure in the elderly is telomere loss. ${ }^{33-37}$ It is known that these highly repeated genetic elements are located at the ends of all eukaryotic chromosomes. ${ }^{38}$ They are necessary for the preservation of genome stability and cell viability because they prevent aberrant recombination and degradation of DNA. During aging, telomere numbers decrease significantly because of replication problems. ${ }^{39}$ Also, this age related telomere loss in germ cells, tumour cells, and leukaemic cells is actively compensated for by a high level of telomerase activity. ${ }^{40-45}$ Theoretically, telomerase activity may be associated with both the level of cellular proliferation and rDNA cistron activity. ${ }^{46}$ Therefore, the changes revealed here in the age related decrease in the proportion of AgNOR staining on metaphase chromosomes in bone marrow erythroid and granulocytic elements may be explained partly by telomere alterations. Such a hypothesis explains why the number of AgNOR positive mitoses in bone marrow samples from patients with mycosis fungoides ${ }^{13}$ and acute lymphoblastic leukaemia (Pedrazzini and Slavutsky, unpublished data) are not age related. In these diseases, mitotically active cells are represented by more immature haemopoietic elements whose telomerase activity is higher than maturating erythroid and granulocytic progenitors. Future investigations should show whether or not the hypothesis is correct.

This work was supported financially by grants from Consejo Nacional de Investigaciones Científicas y Técnicas (CONICET) and from Universidad Nacional de La Plata, Argentina.

1 Hernandez-Verdun D. The nucleolus today. 7 Cell Sci 1991;99:465-71.

2 Roussel P, Hernandez-Verdun D. Identification of Ag-NOR proteins, markers of proliferation related to ribosomal gene activity. Exp Cell Res 1994;214:465-72.

3 Kohno S, Abe S, Matsui S, Sandberg AA. Chromosomes and causation of human cancer and leukemia. XXXVII Nucleolus organizers on the Phl chromosome in chronic myelocytic leukemia. Cancer Genet Cytogenet 1979; 1:15-20.

4 Mamaev NN, Mamaeva SE, Bandyopadhyya D, Medvedeva NV. Study of nucleolar organizer region activity on chromosomes of normal, leukemic and tumor human cells by means of silver staining [Russian]. Tsitologiya 1980;22: $161-7$.

5 Mamaev NN, Mamaeva SE, Liburkina IL, Kozlova TV, Medvedeva NV, Makarkina GN. The activity of nucleolar organizer regions of human bone marrow cells studied with organizer regions of human bone marrow cells studied with
silver staining. I. Chronic myelocytic leukemia. Cancer silver staining. I. Chronic mye
Genet Cytogenet 1985;16:311-20.

6 Mamaev NN, Mamaeva SE, Ushakova EA, Liburkina IL, Poznyak EI. Results of nucleolar organizer region activity study in multiple myeloma [Russian]. Cytologiya Genetics 1985;20:91-7.

7 Mamaev NN, Mamaeva SE, Grabovskaya IL, Makarkina GN, KozlovaTV, Medvedeva NV, et al. The activity of nucleolar organizer regions of human bone marrow cells studied with silver staining. II. Acute leukemia. Cancer Genet Cytogenet 1987;25:65-72.

8 Reeves BR, Casey G, Harris H. Variation in the activity of nucleolar organizer in different tissues, demonstrated by silver staining of human normal and leukemic cells. Cancer Genet Cytogenet 1982;6:223-30.

9 Arden KC, Pathak S, Frankel LS, Zander A. Ag-NOR staining in human chromosomes: differential staining in normal and leukemic bone-marrow samples. Int $\mathcal{F}$ Cancer 1985;36: 647-9.
10 Arden KC, Johnston DA, Cork A, Pathak S. Differential nucleolus organizer activity in normal and leukemic bone marrow. Am f Hematol 1989;30:164-73.

11 Sato Y, Abe S, Kubota K, Sasaki M, Miura Y. Silver-stained nucleolar organizer regions in bone marrow cells and peripheral blood lymphocytes of Philadelphia chromosome-positive chronic myelocytic leukemia patients. Cancer Genet Cytogenet 1986;23:37-45.

12 Mamaev NN, Mamaeva SE. Nucleolar organizer region activity in human chromosomes and interphase nuclei of normal, leukemic and tumor cells as evaluated by silver staining. Int Rev Cytol 1990;121:233-66.

13 Pedrazzini E, Slavutsky I. Ag-NOR staining and satellite association in bone marrow cells from patients with mycosis fungoides. Hereditas 1995;123:9-15.

14 Mamaev NN, Mamaeva SE, Liburkina IL, Kozlova TV, Medvedeva NV, Makarkina GN. Nucleolar organizer region activity in human normal and leukemic cells [Russian]. Tsitologiya 1984;26:46-51.

15 Mamaev NN, Salogub GN, Koloskov AV. Interphase ribosomal RNA cistron staining in chronic myeloid leukaemia. $\mathcal{f}$ Clin Pathol: Mol Pathol 1995;48:M260-3.

16 Grotto HZW, Lorand-Metze I, Metze K. Nucleolar organizer regions in normal hematopoiesis: relationship to cellular proliferation and maturation. Nouv Rev Fr Hematol 1991;33:1-4.

17 Gilberti MFP, Metze K, Lorand-Metze I. Changes of nucleolar organizer regions in granulopoietic precursors during the course of chronic myeloid leukemia. Ann Hematol 1995;71:275-9.

18 Mamaev NN, Salogub GN, Nefedova IB. Interphase ribosomal RNA cistron silver staining in refractory anemias with and without excess blasts. F Clin Pathol: Mol Pathol 1997;50:M92-5.

19 Howell WM, Black DA. Controlled silver-staining of nucleolus organizer regions with a protective colloid developer: a 1-step method. Experientia 1980;36: 1014-15.

20 Denton TE, Liem SL, Cheng KM, Barrett JV. The relationship between aging and ribosomal gene activity in humans as evidenced by silver staining. Mech Ageing Dev 1981;15: $1-7$.

21 Lezhava TA. Age-related dependence of human nucleolar organizer regions [Russian]. Cytologiya Genetics 1984;18: $40-6$.

22 Butler MG, Lane JR. Effects of age, sex and multiple endocrine neoplasia type-II on silver nucleolar organizer crine neoplasia type-II on siver nucleo
regions. Mech Ageing Dev 1989;47:17-24.

23 Lezhava TA, Dvalishvili N. Cytogenetic and biochemical studies on the nucleolus organizing regions of chromosomes in in vivo and in vitro aging. Age 1992;15:41-3.

24 Murasko DM, Weiner P, Kaye D. Decline in mitogen induced proliferation of lymphocytes with increasing age. Clin Exp Immunol 1987;70:440-8.

25 Mauch P, Botnick LE, Hannon EC, Obbagy J, Hellman S. Decline in bone marrow proliferative capacity as a function of age. Blood 1982;60:245-52.

26 Quaglino D, Ginaldi L, Furia N, De Martinis M. The effect of age on hemopoiesis. Aging Clin Exp Res 1996;8:112 .

27 Hartsock RJ, Smith EB, Ketter CN. Normal variation with aging of the amount of hematopoietic tissue in bonemarrow from anterior iliac crest. Am f Clin Pathol 1965;43: 325-33.

28 Lipshitz DA, Udupa KB, Milton KY, Thompson CO. Effect of age on hematopoiesis in man. Blood 1984;63:5029.

29 Anisimov VN. Carcinogenesis and aging. Vol. 1. Boca Raton: CRC Press, 1987:164

30 Nilsson-Ehle H, Jagenburg R, Landahl S, Svanborg A, Westin J. Haematological abnormalities and reference intervals in the elderly. Acta Med Scand 1988;224:595-604.

31 Ames BN, Gold LS. Endogenous mutagens and the causes of aging and cancer. Mutat Res 1991;250:3-16.

32 Chatta GS, Andrews RG, Rodger E, Schrag M, Hammond WP, Dale DC. Hematopoietic progenitors and aging: alterations in granulocytic precursors and responsiveness to recombinant human G-CSF, GM-CSF, and IL-3. F Gerontol 1993;48:M207-12.

33 Vaziri H, Dragowska W, Allsopp RC, Thomas TE, Harley $\mathrm{CB}$, Lansdorp PM. Evidence for a mitotic clock in human hematopoietic stem cells: loss of telomeric DNA with age. Proc Natl Acad Sci USA 1994;91:9857-60.

34 Shay JW, Werbin H, Wright WE. Telomerase shortening may contribute to aging and cancer: a perspective. Mol Cell Diff 1994;2:1-18.

35 Shay JW, Werbin H, Wright WE. You haven't heard the end of it: telomere loss may link human aging and cancer. Can 7 Aging 1995;142:511-24.

36 Wright WE, Shay JW. Time, telomeres and tumors: is celluar senescence more than an anticancer mechanism? Trends Cell Biol 1995;5:293-7.

37 Harley CB, Villeponteau B. Telomeres and telomerase in aging and cancer. Curr Opin Genet Dev 1995;5:249-55.

38 Blackburn EH. Structure and function of telomeres. Nature 1991;350:569-73.

39 Harley CB. Telomeres and aging: fact fancy, and the future. 7 NIH Res 1995;7:64-8.

40 Kim NW, Piatyszek MA, Prowse KR, Harley CB, West MD, Ho PLC, et al. Specific association of human telomerase activity with immortal cells and cancer. Science 1994;266: 2011-15. 
41 Counter CM, Gupta J, Harley CB, Leber B, Bacchetti S. Telomerase activity in normal leukocytes and in hematoTelomerase activity in normal leukocytes a
logic malignancies. Blood 1995;85:2315-20.

42 Hirte HW, Greider CW, Wright WE, Shay JW. Cell immortality, telomerase and cancer. Cold Spring Harbor Symp Quant Biol 1995;59:307-15.

43 Yamakido M. Activation of telomerase in human lymphocytes and hematopoietic progenitor cells. F Immunol 1995;155:3711-15.

44 Norton JC, Piatyszek MA, Wright WE, Shay JW, Corey DR.
Inhibition of human telomerase activity by peptide nucleic acids. Nature Biotechnology 1996;14:615-19.

5 Zhang W, Piatyszek MA Kobayashi T, Estey E, Andreeff M, Deisseroth $\mathrm{AB}$ et al. Telomerase activity in human acute myelogenous leukemia: inhibition of telomerase activity by differentiation-inducing agents. Clin Cancer Res 1996;2: 799-803.

46 Lansdorp PM. Telomere length and proliferation potential of hematopoietic stem cells. F Cell Sci 1995;108: $1-6$. 